\title{
LIMBAH KULIT PISANG SEBAGAI ALTERNATIF PENGGANTI PEWARNA SINTETIS PADA BEDAK TABUR
}

\author{
Asi Tritanti dan Ika Pranita \\ Program Studi Tata Rias Jurusan PTBB FT UNY \\ asi_tritanti@uny.ac.id; ika_pranita@yahoo.co.id
}

\begin{abstract}
This research aims at finding out (1) the process of making banana peel powder that can be used as an alternative for synthetic dyes, (2) the characteristics of banana peel powder product, (3) the result of banana peel coloring powder compared to synthetic coloring, yellow metanil. This study can be categorized as experimental study using two groups of subjects; one group was given a specific treatment while another was used as the control group. The data of the study were collected using labsheets, questionnaires and laboratory testing. Data analysis technique used descriptive statistics, T-Test, and Anova Test. The findings showed that control dye had a bright yellow color while the samples treated with A2 had a dark yellow. Tukey test of A2 treatment showed the score of Tukeytable 3,25<3,80. It means color intensity from A2 treatment was similar to the control group. The result of laboratory testing showed that the sample of banana peel powder with A2 treatment had the water content of 3,72\% in the first test and 3,87 in the second test. Meanwhile, pH value was 6,7 in the first test and 6,6 in the second test.
\end{abstract}

Keywords: Banana Peel Powder, Synthetic Dyes, Loose Powder

\begin{abstract}
ABSTRAK
Penelitian ini bertujuan: (1) mengetahui proses pembuatan serbuk kulit pisang sebagai alternative pengganti pewarna sintetis, (2) mengetahui karakteristik serbuk kulit pisang yang dihasilkan, dan (3) mengetahui hasil akhir pewarna dari serbuk kulit pisang dibandingkan dengan pewarna sintetik metanil yellow. Penelitian ini merupakan penelitian eksperimen, menggunakan dua kelompok subjek, satu kelompok perlakukan dan satu kelompok kontrol Data diperoleh dari lab sheet, angket, dan hasil uji laboratorium. Analisis data menggunakan teknik statistik deskriptif, uji t, dan uji Anova. Hasil penelitian diperoleh pewarna kontrol berwarna kuning cerah, sedangkan sampel perlakuan A2 berwarna kuning tua. Hasil uji tukey perlakuan A2 diperoleh hasil Uji Tukey $_{\text {tabel, }}$ sebesar $3,25<3,80$, dapat disimpulkan bahwa intensitas warna yang dihasilkan perlakuan A2 sama dengan kontrol. Hasil uji laboratorium sampel serbuk kulit pisang dengan perlakuan A2 memiki kadar air sebesar 3,72\% pada uji 1, dan kadar air sebesar 3, 87 pada uji 2 . Nilai pH sampel serbuk kulit pisang sebesar 6,7 pada uji 1, dan 6,6 pada uji 2 .
\end{abstract}

Kata kunci: Serbuk Kulit Pisang, Pewarna Sintetis, Bedak Tabur

\section{PENDAHULUAN}

Kosmetik merupakan salah satu produk yang dipakai berulang-ulang setiap hari, mulai dari rambut hingga ujung kaki. Tidak dapat dipungkiri, baik pria atau wanita menggunakan kosmetik setiap hari sejak kanak-kanak hingga dewasa, bahkan di akhir usia. Kosmetik sudah merupakan bagian tak terpisahkan dari kehidupan manusia. Tingkat kebutuhan yang tinggi akan kosmetik membuat industri ini berkembang pesat untuk memenuhi permintaan masyarakat, dan membuat kosmetik menjadi salah satu bagian dari dunia usaha. Tingkat kebutuhan kosmetik yang terus meningkat bisa dilihat dari jumlah pertumbuhan penduduk setiap tahunnya, membuat industri pembuatan kosmetik bersaing ketat menciptakan produk terbaiknya.

Perkembangan industri kosmetik yang pesat, didukung oleh berkembangnya industri kimia yang menyediakan bahan-bahan pembuat kosmetik, baik sebagai bahan dasar 
maupun bahan aktif. Kemudahan memperoleh bahan dasar dan bahan aktif untuk pembuatan kosmetik ini betul-betul dimanfaatkan secara luas, baik oleh industri skala besar dan industri kecil yang memiliki legalitas resmi dari badan yang berwenang. Namun oleh sebagian kecil kelompok, kemudahan memperoleh bahan dasar dan bahan aktif kosmetik dimanfaatkan untuk mencari keuntungan yang banyak tetapi tidak memperhatikan faktor kesehatan, kenyamanan dan keselamatan konsumen. Pembuatan kosmetik-kosmetik ilegal, dengan bahan-bahan berbahaya semakin marak dan produk-produk tersebut dijual bebas dipasaran dengan menggunakan berbagai strategi. Mulai dari penggunaan wadah bekas kosmetik yang dibuat oleh pabrik berijin resmi, dimana wadah bekas tersebut diperoleh dari pembuangan sampah, hingga membuat label dan ijin yang seolah-olah resmi untuk kemudian dikemas dalam wadah yang banyak dijual di pasaran. Sasaran utama para produsen kosmetik illegal ini adalah masyarakat umum menengah kebawah, dimana tingkat ketelitian, dan kehatihatian memilih kosmetik masih rendah, para pelaku pembuat kosmetik berbahaya menjual produknya dengan harga murah namun dengan janji kualitas yang baik, layaknya produk kosmetik berharga mahal.

Kosmetik-kosmetik berbahaya yang di-temukan adalah kosmetik yang mengandung merkuri, hidroquinon (air keras), rhodamin $B$, dan metanil yellow. Merkuri dan hidroquinon ditemukan pada krim pemutih wajah, dan body lotion, rhodamin $B$ ditemukan pada lipstick, pemerah pipi (blush on), dan eye shadow, sedangkan metanil yellow ditemukan pada bedak. Bedak merupakan salah satu kosmetik yang paling banyak dan sering digunakan. Hampir setiap hari manusia terutama kaum wanita pasti menggunakan bedak, bahkan dalam sehari dapat menggunakannya lebih dari 3 kali. Jika kosmetik bedak mengandung bahan pewarna yang berbahaya maka bahan berbahaya tersebut terpapar pada kulit dalam jumlah yang besar dan dalam waktu yang lama. Terpaparnya kulit dengan bahan metanil yellow dalam jumlah yang besar dan waktu yang lama maka dapat membuat kerusakan kulit yang lebih serius lagi.

Saat ini berdasarkan temuan BPOM, sejumlah bedak wajah di pasaran mengandung bahan kimia yang seharusnya tidak diperbolehkan untuk pembuatan bedak. Bahan paling berbahaya yang sering ditemukan dalam kandungan bedak wajah ialah methanil yellow (pewarna kuning). Ciri bedak padat yang mengandung methanil yellow adalah jika dipakai akan meninggalkan bekas kuning pada pakaian dan sulit untuk dihilangkan. Jika bedak yang memiliki kandungan methanil yellow digunakan secara terus-menerus pada wajah, kulit akan mengalami iritasi bahkan bisa mengakibatkan perubahan pigmen kulit secara signifikan.

Bahan pewarna sintesis/kimia yang berbahaya bagi kulit dapat digantikan dengan pewarna alami yang lebih aman. Dahulu para leluhur menggunakan bahan-bahan alami sebagai pewarna kosmetik, salah satunya adalah kunyit. Kunyit yang memberi warna kuning dengan intensitas cukup kuat dimanfaatkan sebagai pewarna pada lulur, mangir, dan bedak dingin. Saat ini, berdasarkan pengamatan dan hasil-hasil penelitian sebelumnya yang relevan, kulit pisang dapat dimanfatkan sebagai tepung substitusi pada makanan. Tidak menutup kemungkinan bahwa kulit pisang juga dapat dimanfaatkan sebagai bahan pewarna alami pada bedak. Kulit pisang dapat menggantikan bahan pewarna sintetis/kimia yang berbahaya terhadap kulit sehingga dalam penelitian ini diharapkan limbah kulit pisang dapat digunakan sebagai pewarna kosmetik bedak yang aman, murah, dan mempunyai intensitas warna yang tidak kalah dengan warna sintetis.

Tanaman Pisang (Musaceaea sp) merupakan tanaman penghasil buah yang banyak terdapat di Indonesia. Buahnya banyak disukai untuk dikonsumsi secara langsung sebagai buah atau diolah menjadi produk konsumsi lain seperti pisang goreng, cake dari pisang, sale pisang, kripik pisang, selai pisang, dan 
lain sebagainya. Konsumsi buah pisang yang tinggi dapat dilihat dari pola konsumsi pangan sumber vitamin dan mineral penduduk Indonesia selama tahun 2005, 2007, sampai 2010, adalah buah pisang dan daun ketela pohon. Pola konsumsi Pangan Sumber Vitamin Mineral menurut adan Ketahanan Pangan Kementrian Pertanian (2012), menunjukkan bahwa konsumsi Pangan Sumber Vitamin Mineral di Indonesia yang paling banyak adalah pisang setiap tahunnya. Salah satu daerah di Indonesia yang memiliki pola konsumsi Pisang yang tinggi adalah Yogyakarta. Hal ini disebabkan karena Yogyakarta adalah kota pelajar dan pariwisata sehingga penduduknya bertambah dari tahun ke tahun dan berasal dari berbagai daerah. Kondisi Yogyakarta yang seperti ini mendorong untuk membuat berbagai macam diversifikasi makanan olahan yang berasal dari pisang sehingga disukai hampir seluruh lapisan masyarakat. Pola konsumsi pisang yang tinggi dapat dilihat dari produksi pisang di Yogyakarta yang cukup tinggi. Menurut laporan Dinas Pertanian dan Holtikulkura (2011), produksi pisang untuk Provinsi DIY dari tahun 2005-2011 adalah yang terbanyak dari pada tanaman buah yang lain. Produksi yang terbanyak sampai mencapai 60.580 ton pada tahun 2008 .

Pembuatan makanan olahan dari pisang yang tinggi tidak diimbangi dengan pengolahan limbah dari kulit pisang yang sangat banyak jumlahnya. Pemanfaatan limbah kulit pisang masih sangat sedikit yaitu hanya dimanfaatkan sebagai makanan ternak saja, bahkan masih banyak dijumpai limbah ini hanya dibuang begitu saja. Menurut Susanti (2006), kulit pisang adalah bahan buangan (limbah buah pisang) yang cukup banyak jumlahnya. Pada umumnya kulit pisang belum dimanfaatkan secara nyata, hanya dibuang sebagai limbah organik saja atau digunakan sebagai makanan ternak seperti kambing, sapi, dan kerbau. Jumlah kulit pisang yang cukup banyak akan memiliki nilai jual yang menguntungkan apabila bisa digunakan sebagai bahan baku makanan, seperti bahan baku untuk membuat nata dan jelly, serta alternatif bahan penganti pewarna pada kosmetik.

Pemanfaatan limbah kulit pisang yang banyak dapat dimanfaatkan sebagai bahan baku makanan maupun kosmetik. Hal ini sejalan dengan pernyataan Basse (dalam Munadjim, 1998), jumlah dari kulit pisang cukup banyak, yaitu kira-kira 1/3 dari buah pisang yang belum dikupas. Untuk itu limbah kulit pisang banyak dimanfaatkan sebagai olahan disebabkan karena di dalam kulit pisang kandungan gizinya masih cukup lengkap, seperti karbohidrat, lemak, protein, kalsium, fosfor, zat besi, vitamin $\mathrm{B}$, vitamin $\mathrm{C}$, air, dan zat warna karotenoid. Karotenoid adalah zat warna kuning oranye dan merah oranye yang larut dalam lemak tetapi tidak larut dalam air. Karotenoid terdapat pada hampir semua bagian tanaman. Karotenoid terdapat pada jaringan buah (pepaya, mangga), kulit pisang, tomat, lombok merah, ubi jalar, dan didapatkan dalam jaringan produk hewan seperti kuning telur (Munadjim, 1998).

Warna kuning sampai orange dari karotenoid yang terdapat dalam kulit pisang dapat digunakan sebagai bahan pewarna bedak yang dapat menggantikan bahan pewarna bedak sintetis/kimia yang cenderung memiliki potensi efek samping yang lebih besar dari pewarna alami seperti pewarna dari kulit pisang. Pewarna alami memiliki resiko minimal dalam menyebabkan efek samping pada kulit tetapi kelemahannya adalah warna yang dihasilkan dari pewarna alami intensitasnya lebih rendah daripada pewarna sintetis sehingga perlu melakukan modifikasi pada formula bedak dengan bahan pewarna alami.

Menurut Retno dan Fatma (2007), bedak (face powder) termasuk kosmetik dekoratif yang ditujukan untuk menyembunyikan kekurangan pada kulit wajah, misalnya untuk menutupi kulit wajah yang mengkilap (skin imperfection and shininess). Selain untuk menutupi kekurangan pada wajah, tujuan 
pemakaian bedak untuk melindungi dari sinar ultraviolet. Bedak wajah memiliki 2 jenis tipe bentuk yang dapat digunakan, yaitu bedak padat (compact powder) dan bedak tabur (loose powder). Kedua jenis bedak tersebut masing-masing memiliki kelebihan dan kekurangan. Kelebihan bedak padat jika dibandingkan dengan bedak tabur ialah sangat praktis untuk dibawa dan lebih tahan lama di wajah. Bedak tabur, walaupun kurang lama bertahan di wajah, sangat bagus untuk kulit berminyak jika dibandingkan dengan bedak padat (Retno dan Fatma, 2007)

Bedak memiliki beberapa kandungan bahan kimia sintetik dan bahan alami. Pada dasarnya, bahan kimia yang digunakan tidak berbahaya untuk wajah, namun jika digunakan melebihi batas yang diperbolehkan, bahan kimia tersebut dapat merusak kulit wajah. Bahan pewarna pada bedak tabur pada umumnya berasal dari pigmen yaitu pigmen alam maupun pigmen sintetis. Pigmen alam yaitu alumunium silikat, warna yang dihasilkan tergantung pada kandungan besi oksida atau mangan oksida (misal: kuning, coklat, merah bata, dan coklat tua). Pewarna dari pigmen alam tidak berbahaya namun memiliki intensitas warna yang lebih rendah dari pigmen sintetis.

Pewarna sintetis atau dapat disebut juga pigmen sintetis, salah satunya adalah metanil yellow, memiliki nama lain acid sodium salt atau acid yellow36. Metanil yellow merupakan pewarna bersifat asam dan memiliki kepekatan warna hingga $70 \%$, berbentuk serbuk yang solid, larut dalam air $(25 \mathrm{mg} / \mathrm{ml}$ pada suhu $20^{\circ}$ celsius), larut dalam alkohol, bensin dengan kepekatan ringan, dan acetone. Metanil yellow dapat disimpan dan bertahan lama pada suhu ruang $\left(25^{\circ}\right.$ celsius). Metanil yellow memiliki nomor seri MFCD00007486 (Mitsui, 1993).

Kulit pisang memiliki senyawa karotenoid. Zat inilah yang memberi warna pada ekstrak kulit pisang yang dihasilkan. Namun belum diketahui warna yang muncul dari serbuk kulit pisang. Kulit pisang merupakan salah satu bahan yang sangat mudah teroksidasi sehingga dapat dengan cepat menghitam jika dibiarkan dalam udara terbuka. Proses oksidasi ini dapat mengurangi kadar karotenoid dalam kulit pisang. Untuk menjaga dan mempertahankan karoten dalam jumlah yang cukup besar dalam kulit pisang diperlukan senyawa yang dapat menghambat proses penghitaman kulit pisang, yaitu senyawa berupa asam sitrat. Untuk itu diperlukan uji coba pembuatan serbuk kulit pisang. Untuk menghambat proses oksidasi kulit pisang maka limbah kulit pisang akan diolah dengan menambahkan asam sitrat yang berasal dari buah jeruk nipis. Untuk mendapatkan ektsrak berupa serbuk, maka limbah kulit pisang akan diolah melalui proses pengeringan dan penghalusan.

Bedak tabur memiliki karakteristik halus, ringan, dan tidak mengumpal. Bedak tabur me-miliki fungsi sebagai penutup kulit wajah. Bedak tabur akan memberikan lapisan tipis pada permukaan kulit, walaupun karakteristik-nya halus dan ringan, namun bedak tabur memiliki sifat-sifat menutup yang efektif. Agar daya kerja bedak tabur lebih maksimal maka ditambahkan bahan-bahan lainnya dengan memenuhi persyaratan tertentu. Bahan-bahan utama bedak tabur seperti zinx oxide dan titanium dioxide berwarna putih, agar cocok dengan warna kulit maka perlu ditambahkan zat pewarna yang diinginkan. Zat pewarna yang ditambahkan pun harus memenuhi kualifikasi seperti butiran halus, tidak berbau, tidak mudah menggumpal, memiliki pigmen warna yang baik, dan mudah larut dalam air. Untuk itu, ekstrak kulit pisang yang dihasilkan, dan akan digunakan sebagai pewarna alternatif berbahan alami sebagai pengganti pewarna sintetis harus memenuhi kualifikasi karakteristik tersebut.

Pembuatan serbuk kulit pisang dengan menggunakan limbah kulit pisang merupakan salah satu bentuk pemanfaatan limbah kulit pisang secara maksimal. Serbuk kulit pisang ini dapat diharapkan dapat dimanfaatkan sebagai bahan pewarna alami pada bedak. Pewarna alami dari kulit pisang dapat 
menggantikan pewarna sintetis yang banyak beredar dipasaran yang sangat berbahaya bagi kulit jika digunakan dalam jumlah banyak dan jangka waktu yang lama. Pemanfaatan limbah kulit pisang sebagai pewarna alami dalam bedak dapat bersifat aman, murah, dan mempunyai intensitas warna yang tidak kalah dengan pewarna sintesis/kimia.

Kulit pisang sebelumnya sudah dimanfaatkan dalam berbagai kebutuhan, baik makanan, maupun barang tepat guna lainnya.

Pemanfaatan limbah kulit pisang sebagai makanan yaitu sebagai tepung substitusi pengganti tepung terigu, selain itu limbah kulit pisang sebagai absorbent alami multi logam pencemar perairan. Beragamnya manfaat limbah kulit pisang dalam kehidupan, tidak menutup kemungkinan bahwa limbah kulit pisang ini juga dapat dimanfaatkan sebagai pewarna alami yang dapat menggantikan pewarna sintetis pada kosmetik, khususnya bedak tabur. Berdasarkan kondisi yang ada di masyarakat saat ini, kosmetik berbahan alami kembali mendapatkan perhatian khusus, sehingga diharapkan limbah kulit pisang ini dapat dimanfaatkan sebagai alternative pengganti pewarna sintetis.

Permasalahan yang akan dibahas adalah bagaimana proses pembuatan serbuk kulit pisang agar warna yang dihasilkan dapat bertahan dan berwarna cerah, bagaimana karakteristik serbuk kulit pisang yang dihasilkan, dan bagaimana hasil akhir pewarna serbuk kulit pisang dibandingkan dengan pewarna sintetis metanil yellow. Berikut kerangka pikir yang dikembangkan dalam penelitian ini, dapat dilihat pada gambar 1 berikut.

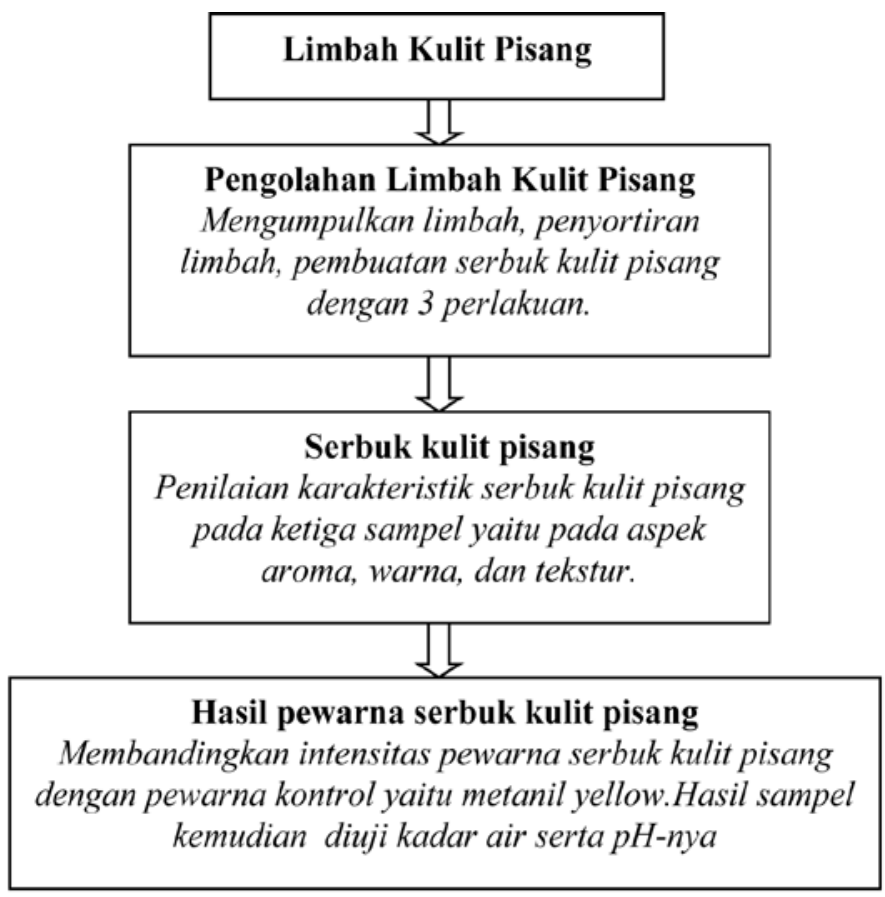

Gambar 1. Kerangka Berpikir Pemanfaatan Limbah Kulit Pisang

\section{METODE}

Penelitian ini merupakan penelitian eksperimen untuk membuat serbuk kulit pisang sebagai alternatif pengganti pewarna sintetis. Pembuatan serbuk kulit pisang melalui 3 (tiga) perlakuan yang berbeda, bertujuan untuk mendapatkan serbuk dengan kualitas yang terbaik. Hasil serbuk kulit pisang yang diperoleh kemudian diamati karakteristiknya, yaitu pada aroma, warna, dan teksturnya. Hasil dari pengamatan karakteristik 
ketiga sampel perlakkan tersebut, kemudian diambil salah satu yang paling baik dan mendekati pewarna kontrol, untuk kemudian dibandingkan intensitas warnanya dengan pewarna sintetis (Metanil Yellow) sebagai pewarna kontrol. Serbuk kulit pisang yang warnanya paling mendekati pewarna kontrol kemudian dianalisis melalui uji laboratorium untuk mengetahui nilai kadar air dan nilai $\mathrm{pH}$ nya.

Prosedur eksperimen yang dilakukan yaitu : (1) pengumpulan limbah dan penyortiran limbah kulit pisang; (2) pembuatan serbuk kulit pisang melalui 3 perlakuan; (3) replikasi masing-masing perlakukan sebanyak 3 kali; (4) penilaian karakteristik estrak kulit pisang meliputi tekstur, warna, dan aroma; (5) penilaian intensitas warna serbuk kulit pisang, dengan membandingkan sampel dengan pewarna control; (6) uji analisis kadar air serbuk kulit pisang untuk hasil serbuk kulit pisang yang paling mendekati pewarna kontrol kandungan kadar air tidak boleh melebihi nilai 5\%, karena jika sediaan memiliki nilai kadar air lebih dari 5\% maka sangat berpotensi sebagai media pertumbuhan jamur dan bakteri; (7) uji kadar $\mathrm{pH}$ serbuk kulit pisang untuk hasil serbuk kulit pisang yang paling mendekati pewarna kontrol, dengan rentang nilai harus berada pada level netral yaitu pada nilai $\mathrm{pH} 4,00-6,5$; dan (8) membandingkan pewarna serbuk kulit pisang dengan pewarna sintetis metanil yellow.

Pengumpulan data dalam penelitian ini menggunakan instrument labsheet, angket, dan hasil uji laboratorium. Untuk memperoleh data prosedur pembuatan serbuk kulit pisang digunakan lab sheet. Untuk memperoleh data karateristik serbuk kulit pisang, digunakan instrument penilaian karakteristik serbuk kulit pisang. Untuk memperoleh data perbandingan pewarna serbuk kulit pisang dengan pewarna control digunakan instrumen penilaian intensitas warna sampel dan kontrol. Untuk menunjang pengumpulan data, sampel yang dibandingkan dengan pewarna control diuji untuk mengetahui kadar air dan nilai $\mathrm{pH}$-nya.
Analisis data menggunakan teknik analisis deskriptif, yaitu teknik pengolahan data bertujuan untuk melukiskan dan menganalisis kelompok data tanpa membuat atau menarik kesimpulan (Arikunto, 2008). Teknik statistic deskriptif digunakan untuk menjawab rumusan masalah tentang karakteristik dari serbuk kulit pisang (bentuk, warna, bau, dan tekstur). Selain itu digunakan juga uji untuk mengetahui apakah ada perbedan hasil akhir intensitas warna antara pewarna sampel terhadap pewarna sintetik. Uji Anova digunakan untuk me-ngetahui apakah ada perbedaan bermakna dari sampel pewarna serbuk kulit pisang terhadap intensitas warna yang dihasilkan yang menyerupai atau mendekati pewarna sintetik metanil yellow. Hipotesis dalam penelitian ini adalah limbah kulit pisang dapat digunakan sebagai pengganti pewarna sintetik pada bedak tabur.

\section{HASIL DAN PEMBAHASAN}

Serbuk kulit pisang dihasilkan setelah melalui serangkaian proses. Kelemahan kulit pisang salah satunya adalah sangat mudah teroksidasi, dan menyebabkan perubahan warna menjadi kehitaman. Untuk itu diperlukan perlakuan tertentu untuk dapat menghambat proses oksidasi pada kulit pisang. Apabila kulit pisang segar yang telah bersih dikeringkan, maka dalam waktu relatif singkat kulit pisang akan menghitam. Oleh sebab itu kulit pisang ditreatment dengan tiga perlakuan berbeda untuk mengetahui proses perlambatan oksidasi jika kulit pisang diberi larutan asam sitrat. Berdasarkan ketiga perlakuan yang diterapkan untuk menghasilkan serbuk kulit pisang yang memenuhi syarat pewarna kosmetik yaitu tidak berbau, memiliki butiran halus, tidak mudah menggumpal, dan memiliki pigmen warna yang baik, maka proses yang menghasilkan serbuk kulit pisang yang mendekati syarat tersebut adalah pada kulit pisang yang diperlakukan dengan direbus dalam larutan air jeruk lalu didiamkan dalam rendaman tersebut hingga air menjadi dingin, 
untuk kemudian ditiriskan, dihaluskan hingga menjadi puree kulit pisang, kemudian dikeringkan menggunakan cabinet dryer selama 24 jam, dan hasil akhir yang telah kering dihaluskan berkali-kali hingga memenuhi derajat kehalusan yang ditentukan, yaitu dapat melewati saringan dengan kerapatan 100-150 mesh. Hasil sampel ini untuk kemudian di uji di laboratorium untuk me-ngetahui kadar air dan nilai $\mathrm{pH}$ serbuk kulit pisang. Berdasarkan hasil uji laboratorium yang dilakukan di CV. Chem-Mix Pratama, diperoleh hasil seperti yang disajikan pada tabel 1 berikut.

Tabel. 1 Nilai Kadar Air dan Nilai Ph Serbuk Kulit Pisang

\begin{tabular}{cccc}
\hline & & Ulangan 1 & Ulangan 2 \\
\hline Pengujian & Nilai & \multicolumn{2}{c}{ Serbuk Kulit Pis ang } \\
\hline Kadar Air & $<5 \%$ & $3,7194 \%$ & $3,8745 \%$ \\
$\mathrm{pH}$ & $>6,5$ & 6,7 & 6,6 \\
\hline
\end{tabular}

Pada penelitian ini, untuk mendapatkan serbuk kulit pisang, maka limbah kulit pisang diolah dengan menerapkan 3 (tiga) perlakuan berbeda. Masing-masing perlakuan dilakukan replikasi uji coba sebanyak 3 (tiga) kali. Pada perlakuan A1, uji coba pertama dilakukan dengan cara merendam kulit pisang dalam air panas, kemudian ditiriskan, dan direndam kembali menggunakan air jeruk nipis sebanyak $50 \mathrm{ml}$ dicampur dengan air tawar dingin sebanyak $500 \mathrm{ml}$. Hasil yang diperoleh adalah serbuk kulit pisang berwarna coklat tua cenderung hitam, dengan tekstur yang sangat keras. Pada saat dihaluskan, kulit pisang tidak dapat halus dengan sempurna dan berserat karena teksturnya yang sangat keras. Untuk itu pada replikasi A1, melalui uji coba kedua, perlakuan diterapkan sedikit berbeda, yaitu tetap merendam kulit pisang dalam air panas dengan suhu $90^{\circ}$ celcius selama 15 menit, untuk kemudian kulit pisang dibiarkan dalam rendaman tersebut hingga dingin, dan setelah dingin kulit kemudian ditiriskan. Kulit pisang kemudian direndam kembali dalam campuran air jeruk nipis dingin namun dengan konsentrasi asam sitrat yang lebih pekat yaitu sebanyak $100 \mathrm{ml}$ sari jeruk nipis dalam $500 \mathrm{ml}$ air tawar. Perendaman dilakukan selama 30 menit, kemudian kulit pisang ditiriskan lalu dikeringkan.

Hasil yang diperoleh adalah kulit pisang berwarna sedikit lebih muda dari uji coba pertama, yaitu berwarna coklat dan teksturnya masih kasar namun tidak berserat. Berdasarkan sedikit perbedaan perlakuan pada replikasi kedua maka perlakuan tersebut diterapkan kembali pada uji coba ketiga, dan diperoleh hasil yang sama dengan uji coba kedua. Melalui ketiga uji coba yang dilakukan pada perlakuan A1 diperoleh kesimpulan bahwa pekatnya sari jeruk nipis dalam air rendaman dapat menghambat oksidasi sedikit lebih lama, dan proses perendaman yang cukup lama (30 menit) membuat kulit pisang lebih lunak sehingga setelah dikeringkan membuat teksturnya sedikit lebih halus apabila dibandingkan dengan hasil uji coba pertama.

Pada perlakuan A2, uji coba pertama dilakukan dengan cara merebus kulit pisang dengan larutan air jeruk nipis selama 5 menit, lalu membiarkan air dan kulit pisang tersebut menjadi lebih dingin, untuk kemudian ditiriskan dan dikeringkan. Diperoleh hasil serbuk kulit pisang berwarna coklat dengan tekstur yang kasar. Uji coba kedua dilakukan dengan menambahkan durasi perebusan, yang semula selama 5 menit menjadi 10 menit, namun dengan menerapkan perlakuan yang sama seperti uji coba pertama. Diperoleh hasil serbuk kulit pisang dengan warna kuning tua, dan tekstur yang halus setelah melalui 4 kali proses penghalusan. Namun tekstur halus ini belum mampu menembus saringan dengan kerapatan 100 mesh walaupun penghalusan dilakukan kembali lebih dari 5 kali. Untuk itu pada uji coba ketiga, perlakuan disiasati dengan cara menghaluskan kulit pisang setelah proses perebusan dan air rebusan menjadi agak 
dingin sehingga diperoleh bubur kulit pisang. Bubur kulit pisang ini bentuknya menyerupai bubur bayi, namun lebih kental dan lengket. Hal ini karena kulit pisang memiliki getah, dan getah tersebut menjadi lebih banyak karena proses penghalusan dalam kondisi basah. Proses pengeringan memakan waktu lebih lama karena kulit pisang berada dalam kondisi lengket dan pekat.

Dengan perlakuan yang sama dengan uji coba kedua, maka pada uji coba ketiga ini diperoleh hasil warna serbuk kuning tua namun cerah, dan tekstur serbuk sangat lembut. Setelah melalui 4 kali proses penghalusan dan pengayakan, serbuk ini dapat melewati saringan dengan kerapatan 100 mesh. Melalui perlakuan A2 dan ketiga uji coba yang dilakukan, dapat ditarik kesimpulan bahwa serbuk kulit pisang yang dihasilkan jauh lebih baik bila dibandingan dengan perlakuan A1. Hal ini dipengaruhi antara lain oleh adanya proses perebusan menggunakan air bersifat asam, sehingga proses oksidasi terhambat, dan lunaknya tekstur kulit pisang memberi bentuk yang lebih halus pada serbuk yang dihasilkan.

Pada perlakuan A3, ujicoba pertama dilakukan dengan menerapkan perlakuan merendam kulit pisang dalam air jeruk panas bersuhu $90^{\circ}$ celcius selama 5 menit, kemudian ditirskan, dan kulit pisang direndam kembali dalam air dingin tawar selama 15 menit. Hasil yang diperoleh serbuk kulit pisang berwarna coklat tua, dan tekstur kulit pisang yang sangat keras sehingga setelah melalui proses penghalusan, serbuk masih banyak mengandung serat.Pada ujicoba kedua, durasi perendaman kulit pisang dalam air jeruk nipis panas ditambah, yaitu dengan cara membiarkan air hingga suhu turun (hangat), kemudian kulit pisang ditiriskan dan direndam air dingin dengan durasi sama dengan uji coba kedua. Hasil yang diperoleh yaitu warna serbuk coklat cerah namun tekstur serbuk masih kasar. Pada uji coba ketiga, dengan perlakuan yang sama, proses penghalusan dilakukan di awal, yaitu setelah kulit pisang direndam air dingin, selanjutnya tanpa ditiriskan, kulit pisang dihaluskan lalu dikeringkan. Hasil yang diperoleh adalah serbuk berwarna coklat cerah, namun tekstur tetap kasar. Berdasarkan ketiga ujicoba pada perlakuan A3, dapat disimpulkan bahwa tidak ada perubahan signifikan yang terjadi pada warna dan tekstur serbuk kulit pisang. Secara umum, hasil dari perlakuan A3 hampir sama dengan hasil perlakuan A1.

Tiga perlakuan yang diterapkan dalam proses pembuatan serbuk kulit pisang diperoleh hasil bahwa perlakuan A2, yaitu merebus kulit pisang dalam larutan jeruk nipis selama 10 menit, dan membiarkan hingga suhu air turun memberi pengaruh pada warna kulit pisang. Proses oksidasi bisa dihambat sehingga kulit pisang tidak lekas menjadi coklat dalam proses pengeringan. Selain itu perebusan juga memperbaiki tekstur kulit pisang dan memberi pengaruh pada kehalusan serbuk yang dihasilkan. Proses penghalusan kulit pisang di awal, setelah perebusan juga turut mempengaruhi tekstur serbuk kulit pisang, sehingga menjadi lebih lembut dan halus.

\section{Karakteristik Serbuk Kulit Pisang yang Dihasilkan \\ Penilaian karakteristik serbuk kulit} pisang mencakup aspek aroma, warna, dan tekstur. Ketiga aspek ini dimuat dalam sebuah angket, yang diisi dengan jalan mengamati, meraba, dan mencium seluruh sampel serbuk kulit pisang. Pada ujicoba ke-1 diperoleh hasil sampel dengan perlakuan A1 memiliki aroma wangi selayaknya pisang, dengan aroma yang lembut, memiliki warna yang coklat tua cenderung kehitaman dengan tekstur yang keras sebelum dihaluskan, dan berserat setelah proses penghalusan. Sampel dengan perlakuan A2 diperoleh hasil serbuk kulit pisang yang tidak berbau/ tidak ada aroma apapun, tampilan warna serbuk yang coklat dan tekstur yang kasar.Sampel dengan perlakuan A3 diperoleh hasil memiliki aroma wangi pisang yang samar-samar, memiliki warna coklat tua cenderung hitam dengan tekstur berserat.

Pada ujicoba ke-2, sampel dengan perlakuan A1 diperoleh hasil serbuk kulit pisang dengan aroma wangi pisang yang tegas, warna serbuk coklat dengan tekstur kasar. Perlakuan A2 memberikan hasil serbuk kulit pisang yang tidak berbau, warna serbuk kuning tua, dengan tekstur yang halus namun tidak dapat melewati saringan dengan diameter 100 mesh. Sampel dengan perlakuan A3 memiliki serbuk kulit pisang yang beraroma pisang yang 
samar, dengan warna coklat dan tekstur kasar namun tidak berserat.

Pada ujicoba ke-3, sampel dengan perlakuan A1 diperoleh hasil serbuk kulit pisang yang memiliki aroma wangi pisang, memiliki warna coklat, dan tekstur kasar. Sampel dengan perlakuan A2 memiliki serbuk kulit pisang yang tidak berbau, warna kuning muda, dan tekstur yang halus dan lembut, dan dapat melewati saringan dengan diameter 100 mesh. Sampel dengan perlakuan A3 memiliki hasil serbuk kulit pisang dengan aroma wangi pisang yang samar, berwarna coklat dan tekstur kasar.

Berdasarkan ketiga uji coba yang dilakukan, maka hasil sampel yang paling memenuhi syarat karakteristik pewarna kosmetik yang tidak berbau, bertekstur halus, dan memiliki warna mendekati dengan warna kontrol adalah sampel dengan perlakuan A2. Hasil perlakuan A1 dan A3 tidak memenuhi syarat pewarna kosmetik yang baik karena teksturnya kasar dan berserat. Perlakuan A1 da A3 untuk kemudian diperlakukan sama dengan proses A2, yaitu pada tahap kedua, kulit pisang direbus, namun hasilnya serbuk kulit pisang tetap memiliki tekstur yang kasar, dan warna menjadi lebih gelap.

Berdasarkan pengamatan pada karakteristik pewarna kosmetik, sampel tersebut untuk kemudian dibandingkan dengan pewarna kontrol (metanil yellow). Hasil perbandingan diperoleh data bahwa pewarna kontrol memiliki warna kuning cerah, sedangkan sampel memiliki warna kuning tua. Berdasarkan hasil pada keempat tabel diatas, maka dilakukan uji asumsi, yaitu dengan uji normalitas menggunakan KolmogorovSmirnov pada taraf signifikansi 0,05 , diperoleh hasil Uji normalitas sebesar 0,2, dengan demikian dapat simpulkan bahwa sampel diambil dari populasi yang berdistribusi normal karena 0,2 >0,05. Uji homogenitas menggunakan Bartlet test diperoleh nilai 0, 01, dan dapat disimpulkan semua populasi memiliki varian yang sama karena nilai $0,01<$ 0,05 .
Uji berikut yang dilakukan adalah uji Anova satu arah, diperoleh hasil $\mathrm{F}_{\text {hitung }}>\mathrm{F}_{\text {tabel }}$ dengan nilai $25,57>2,9$, dengan demikian diperoleh putusan hipotesis Ho ditolak dan H1 diterima, yang artinya ada paling sedikit satu perlakuan yang menghasilkan intensitas warna yang berbeda dengan dua perlakuan lainnya. Uji lanjut yang dilakukan adalah uji tukey untuk mengetahui perlakuan mana yang berbeda dengan perlakuan lainnya. Hasil yang diperoleh adalah nilai uji tukey perlakuan A1 > nilai tukey tabel, yaitu $8,63>3,80$ dan $5,38>$ 3,80. Demikian pula dengan perlakuan A3, diperoleh nilai sebesar 8,10>3,80 dan 4,85> 3,80. Nilai uji Tukey untuk perlakuan A2 diperoleh hasil < nilai Uji Tukeytabel, sebesar $3,25<3,80$. Berdasarkan hasil uji Tukey dapat ditarik kesimpulan bahwa intensitas warna yang dihasilkan per-lakuan A2 sama dengan kontrol sedangkan intensitas warna perlakuan A1 dan A3 tidak sama dengan kontrol.

Untuk memperkuat hasil akhir dan menegaskan hipotesis, maka pewarna yang berasal dari serbuk kulit pisang dianalis untuk mengtahui kadar air dan nilai $\mathrm{pH}$ yang terkandung di dalamnya. Hasil uji laboratorium menunjukkan bahwa sampel serbuk kulit pisang dengan perlakuan A2 memiki kadar air sebesar 3,72 \% pada uji ulangan 1, dan kadar air sebesar 3, 87 pada uji ulangan 2. Nilai pH sampel serbuk kulit pisang sebesar 6,7 pada uji ulangan 1 , dan 6,6 pada uji ulangan 2 .

Dengan nilai kadar air 3,72\%, dan nilai pH 6,7 maka dapat disimpulkan bahwa serbuk kulit pisang memiliki potensi untuk dapat digunakan sebagai alternative peng-ganti pewarna sintetis pada bedak tabur. Kadar air $3,72 \%$ berarti serbuk kulit pisang memiliki kadar air sebesar 3,72\%. Nilai ambang batas kadar air adalah 5\%, jika lebih dari 5\% maka sediaan kosmetik memiliki potensi sebagai media pertumbuhan bakteri dan jamur. Nilai kadar air serbuk kulit pisang yang berada di bawah 5\% dapat diartikan bahwa serbuk kulit pisang memiliki potensi yang kecil sebagai 
media pertumbuhan jamur dan bakteri. Selain itu nilai kadar dibawah 5\% membuat serbuk kulit pisang dapat disimpan dengan masa simpan selama kurang lebih 6 (enam) bulan, di dalam wadah kedap udara.

Nilai $\mathrm{pH}$ seimbang kulit adalah 4,5 6,5. Serbuk kulit pisang memiliki nilai $\mathrm{pH} 6,7$, artinya memiliki potensi dan cukup memenuhi syarat untuk digunakan sebagai salah satu bahan kosmetik. Dengan demikian, uji kadar air dan nilai $\mathrm{pH}$ menguatkan hipotesis yang dibuat, bahwa serbuk kulit pisang dapat dijadikan alternative pengganti pewarna sintetik. Warna yang dihasilkan serbuk kulit pisang yaitu coklat tua. Warna ini apabila digunakan sebagai pewarna dalam kosmetik akan menghasilkan warna bedak yang mengarah pada warna kuning langsat.

\section{SIMPULAN}

Berdasarkan penelitian dan hasil yang diperoleh, maka dapat disimpulkan bahwa untuk membuat serbuk kulit pisang dengan warna mengarah pada warna kuning tua, memiliki tekstur halus, dan tidak beraroma dapat dilakukan dengan cara merebus kulit pisang dalam larutan air jeruk nipis selama 10 menit, lalu air dan kulit pisang dibiarkan hingga suhu turun (hangat), kemudian rebusan tersebut dihaluskan menggunakan blender, dikeringkan, dan hasil adonan yang telah kering dihaluskan kembali untuk kemudian diayak. Hasil serbuk yang di-peroleh disimpan dalam wadah tertutup rapat dan kedap udara. Larutan air jeruk nipis berguna untuk menghambat proses oksidasi pada kulit pisang sehingga kandungan karotenoid pada kulit pisang masih dapat bertahan.

Karakteristik pewarna kosmetik yang baik adalah tidak berbau, bertekstur halus dan lembut, dan tidak mudah menggumpal. Serbuk kulit pisang dengan perlakuan A2 memiliki karakteristik tidak beraroma/tidak berbau, memiliki warna kuning tua, dan memiliki tekstur halus dan dapat melewati saringan dengan diameter 100 mesh. Serbuk kulit pisang dengan perlakuan A2 tidak beraroma/tidak berbau karena melewati proses perebusan, penghalusan dan penge-ringan. Warna kuning tua pada serbuk kulit pisang diperoleh dari penambahan larutan jeruk nipis yang dipanaskan (direbus) sehingga proses oksidasi terhambat, selain itu proses penghalusan segera setelah rebusan kulit pisang suhunya turun juga member pengaruh terhadap warna serbuk yang dihasilkan. Suhu pengeringan ekstrak basah kulit pisang dijaga pada suhu sinar matahari yaitu $60^{\circ}-70^{\circ}$ celcius. Hal ini bertujuan agar ekstrak basah kulit pisang tidak gosong dan warnanya dapat menjadi lebih coklat.

Hasil akhir pewarna alami serbuk kulit pisang mendekati warna metanil yellow, yaitu serbuk kulit pisang berwarna kuning tua, sedangkan metanil yellow berwarna kuning cerah. Selain itu serbuk kulit pisang memiki kadar air 3,72\% dan nilai pH 6,7. Berdasarkan hasil tersebut, maka dapat disimpulkan bahwa pewarna alami serbuk kulit pisang dapat digunakan untuk menggantikan metanil yellow sebagai pewarna alternative pada kosmetik dekoratif bedak tabur. Dengan kadar dibawah $5 \%$ membuat serbuk kulit pisang dapat disimpan dengan masa simpan selama kurang lebih 6 (enam) bulan, di dalam wadah kedap udara. Warna kuning tua yang dihasilkan serbuk kulit pisang apabila digunakan sebagai pewarna dalam kosmetik akan menghasilkan warna bedak yang mengarah pada warna kuning langsat.

\section{DAFTAR RUJUKAN}

Badan Ketahanan Pangan Kementrian Pertanian. 2012. Roadmap diversifikasi pangan 2011-2015. Diambil pada tanggal 22 Maret 2014, dari www. Perpustakaan.bappenas.go.id/.../templateDetail.jsp

Dinas Tanaman Pangan dan Holtikulutura. 2011. Laporan tahunan Tahun 2011 Provinsi DIY. Diambil pada tanggal 22 Maret 2014 
Munadjim. 1998. Teknologi pengolahan pisang. Jakarta: Gramedia

Retno Iswari T. \& Fatma Latifah. 2007. Buku pegangan ilmu pengetahuan kosmetik. Jakarta: Gramedia Pustaka Utama

Arikunto, Suharsimi \& Cepi Safruddin Abul Jabar.2008. Evaluasi program pendidikan. Jakarta: Bumi Aksara

Susanti, Lina. 2006. Perbedaan penggunaan jenis kulit pisang terhadap kualitas nata. Skripsi Universitas Negeri Semarang, Semarang

T. Mitsui. 1993. New cosmetics science. Amsterdam : Elseiver Science B.V. 